短報

\title{
相模川沿岸に分布する中津層群塩田層のテフラと そのフィッション・トラック年代
}

野田啓司*1 • 奥 村 清*2

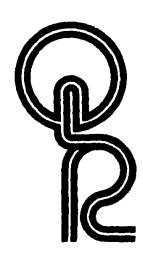

相模川沿岸の中津層群最上部塩田層に挾在する 190 層のテフラの層序, 岩相, 記載岩石学的性 質を明らかにし，その層序位置を示した．これらのテフラには，全鉱物中の石英の含有量が $12 \%$ で，ジルコンの含有比が高い Sd100, 重鉱物が角閃石と不透明鉱物からなる特徵をむつ $\mathrm{Sd} 22, \mathrm{Sd}$ $23, \mathrm{Sd} 24$ などがあることを明らかにした. また, Sd100のフィッション・トラック年代を測定し, $2.1 \pm 0.5 \mathrm{Ma}$ という值を得た。

キーワード : 中津層群, 塩田層, テフラ, フィッション・トラック年代

\section{I. は じめに}

中津層群は, 神奈川県北西部に広がる丹沢山地の東に 分布し，県央を流れる相模川およびその支流の中津川の 河床とその周辺の段丘崖に露出する. そして, 多数の貝 化石, ゾウやサルなど哺乳類化石を産出する (小泉・長 谷川, 1988 ; 長谷川ほか, 1994).

中津層群の年代について, 軟体動物化石（鈴木，1932； 馬場, 1992 ; 奥村ほか, 1997 ; Okumura and Ueda, 1998 など), 有孔虫化石 (中世古・澤井, 1950), 石灰質 ナンノ化石 (岡田, 1987), 浮遊性有孔虫群集と古地磁気 層序による堆積年代学的研究 (斎藤, 1988) などの研究 によって, 鮮新世後期または更新世初期とされている. 中津層群上部には多くのテフラが挾在しているが, こ れらの性質については小池・村井 (1950), 野田ほか （1999）による一部のものについての報告があるのみで, 大部分については明らかにされていない，そこで，本稿 では中津層群塩田層に挾在するテフラの詳細な層序, 岩 相, 記載岩石学的性質およびフィッション・トラック年 代 (以下, FT 年代とする)を明らかにする.

\section{II. 中津層群の層序区分と塩田層}

2000 年 8 月 23 日受付. 2001 年 11 月 17 日受理.

*1 海老名市立大谷中学校 T243-0411 海老名市大谷 3535. E-mail

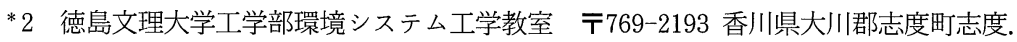

中津層群は基盤の中生界小仏層群を不整合に覆い，上 部更新統の段丘堆積物に覆われる. 鈴木 (1932) になら い, Ito (1985) は中津層群を下部より上部に向かって, 小沢層, 神沢層, 清水層, 大塚層, 塩田層に区分した(図 1).

奥村ほか (1997) は, 大塚層は塩田層に比べてテフラ の挾在頻度が小さいとしている. 本研究では, 調査地点 23 (図 2) で認められるスコリア層 (Sd1) を境として, そ の上位はテフラの挾在比が非常に大きいことから, Sd1 より上位を塩田層と定義する. 塩田層は層厚 $72 \mathrm{~m}$ を有 し，190 層のテフラを挾在し，上部ほどテフラの挾在す る割合を増す。

\section{III. テフラの命名および観察・試料採取地点}

今回新たに最下位から上位へ向かって順に, テフラを $\mathrm{Sd} 1$ から Sd190 まで $\mathrm{Sd}$ 番号で命名した. 各テフラの挾 在層準を図 3 に示す．相模川右岸では全テフラが露出す るが, 左岸では Sd19〜Sd77 の層準が観察できる.

テフラの観察および試料の採集地点は, 厚木市上依点 から愛川町六ツ倉にかけての相模川右岸の段丘崖 (図 2, 地点 1 36), および相模原市塩田から塩田石切までの相 模川左岸の段丘崖 (図 2, 地点 37〜 50) である. 

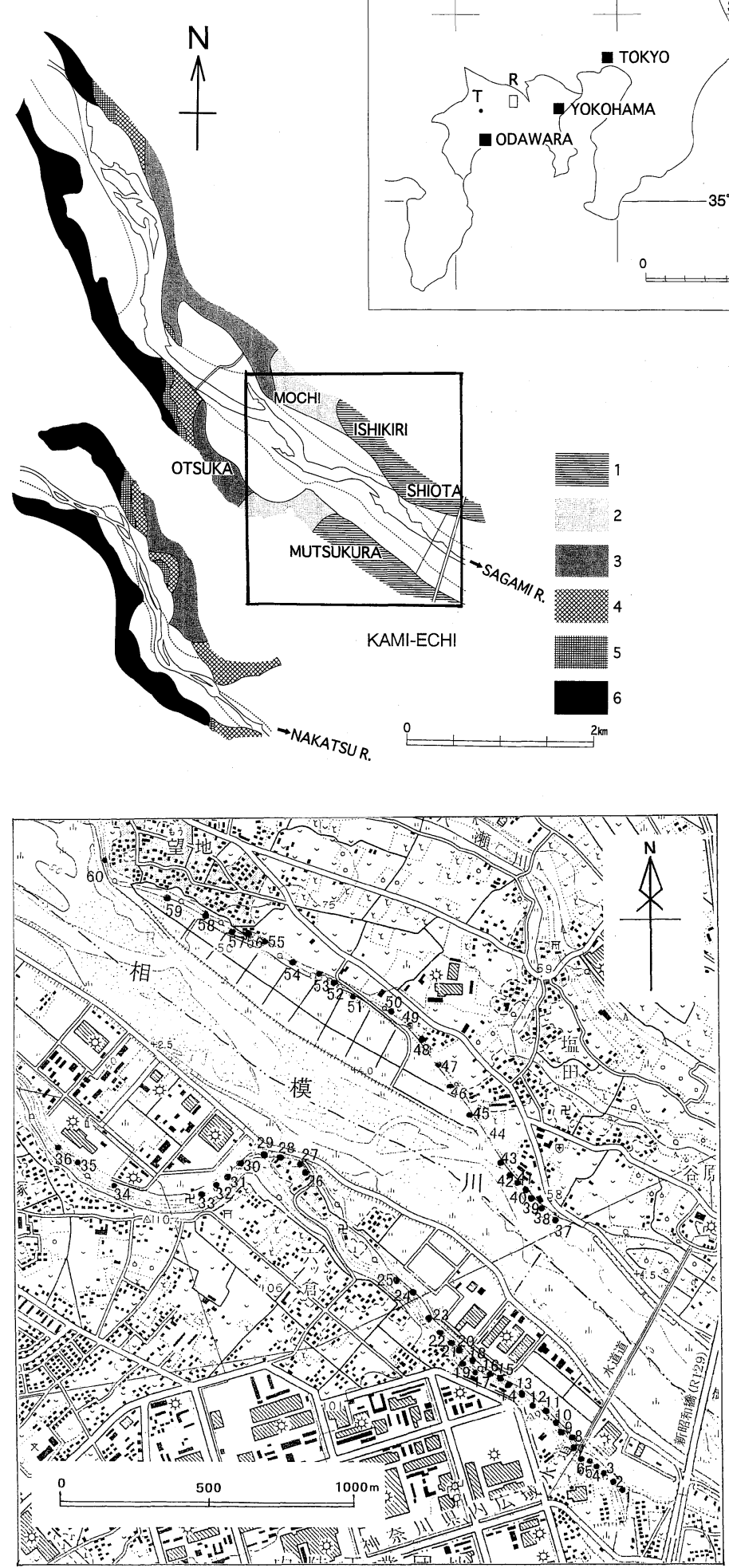

図 1 中津層群の地質

团った部分は調査範囲 (図 2). $\mathrm{T}$ : 丹沢 山塊 $\mathrm{R}$ : 調查地点 1 . 塩田層 2 . 大 塚層 3. 清水層 4. 神沢層 5. 小沢層 6. 小仏層群 野田ほか (1999) による.
図 2 調查範囲

$1 \sim 60$ が調查地点. 国土地理院発行 2.5 万 分の 1 地形図「上溝」を使用。 

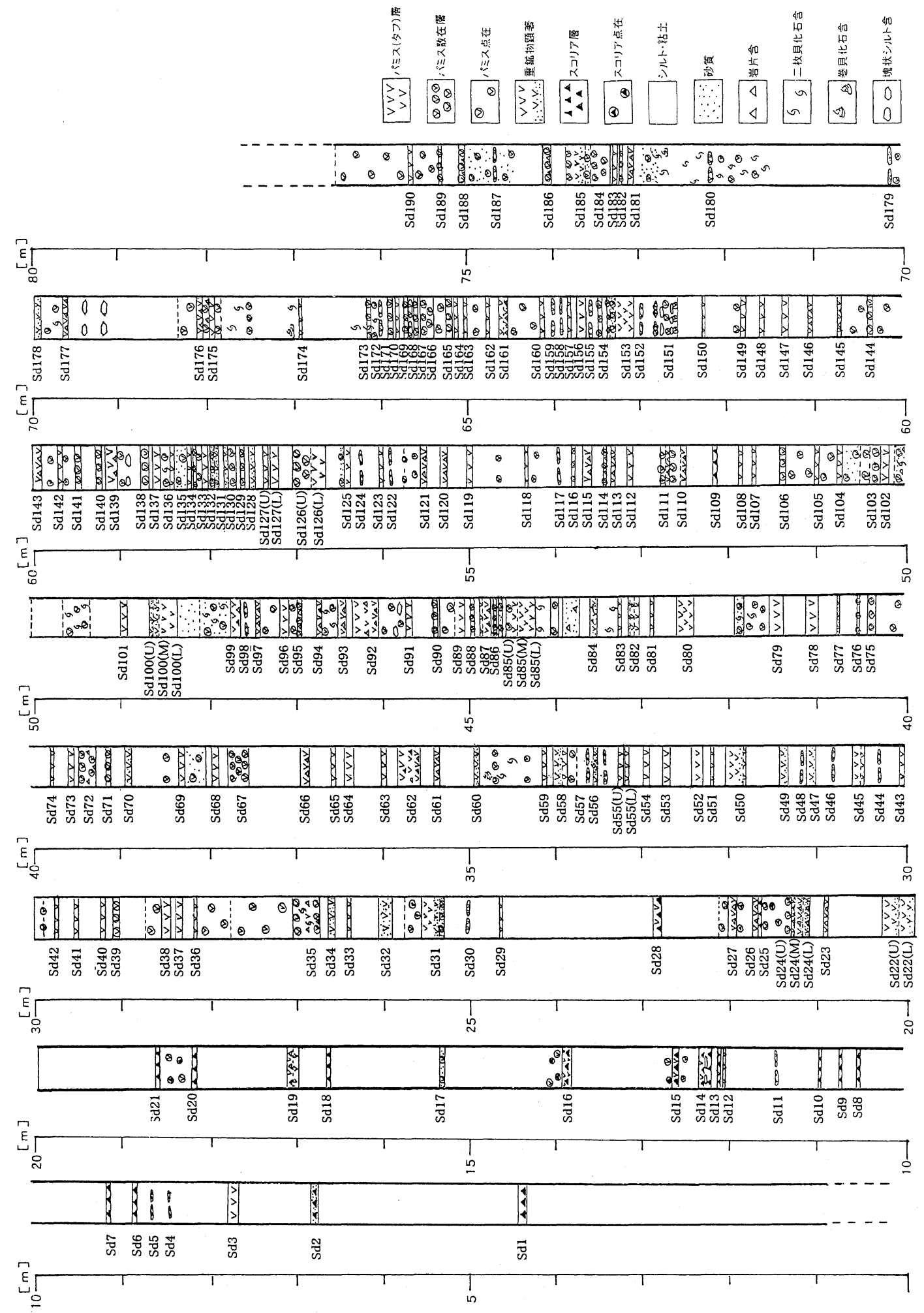


\section{IV. テフラの岩相上の特徵}

各テフラの岩相, 層厚および構成物質等を付表に示し た. また，重鉱物が特に目立つむのについてはそれを記 した．粒径 $4 \mathrm{~mm}$ 以上の啋を含むむのについては，その 最大粒径を示した.

テフラの層厚は最大 $42 \mathrm{~cm}$ で, 薄いシルト層を挾むむ の，下部のスコリア層と上部のパミス層のセットからな るあのがある. 内部構造には厚さ $0.5 \sim 1 \mathrm{~cm}$ の葉理, 正 級化構造, 逆級化構造などがみられる.

テフラは，岩相によって軽石を主体とする軽石質テフ ラ，有色鉱物が顕著なテフラ，スコリアを主体とするス コリア質テフラの 3 つのタイプに分類される. さらに, スコリア質テフラはスコリア層とスコリア点在層に分類 できる. Sd1〜Sd21 の範囲には, スコリア質テフラか顕 著で，これより上位では少ない。

テフラには, 二次的に堆積したと思われるあの, 砂, 礫，化石片等が混在するあのがあり，それらを以下の基 準によって純度 (Grade) A，B，Cに分けた。

純度 $\mathbf{A}$ : テフラがいったん堆積したあと, 流水による 移動や，流水による侵食の痕力認められないあの．側方 への層厚変化がほとんどなく, 砂や砅等の砕屑物を含ま ない。

純度 B : 側方への連続力゙断片的，あるいは泥層の中な どにレンズ状に挾在し，流水による侵食の跡が認められ ることあある. 水流による堆積構造がみられ，砂や円磨 された礫を含むことがある.

純度 $\mathrm{C}$ : 円磨された碟, 砂からなる磻層, 砂層および 粘土層の中に, テフラが散在しているもの.

純度 $\mathrm{A}$ のテフラは全体の $73 \%$, 純度 B は $10 \%$, 純度 C は $17 \%$ で, 純度 $\mathrm{A}$ が全体の $3 / 4$ を占めている。これ らのことから, 多くのテフラは堆積当時の性質をそのま ま有していると思われる。

\section{V. 記載岩石学的性質}

各テフラの記載岩石学的性質を付表に示す.

全構成鉱物の組成比については, 採取した試料を水 洗・穊分けした後, 粒径 $1 / 4 \sim 1 / 16 \mathrm{~mm}$ のテフラをプレ パラートに固定し，200 粒以上について種類を同定し た. 図 4 には各テフラの火山ガラス $(\mathrm{Gl})$, 軽鉱物 $(\mathrm{Fel}+$ Qz), 重鉱物（H.M.）の含有比（粒数\%）を示した. Cook (1965) の区分に従い, 火山ガラス以外の鉱物の含 有量 10\%，25\%，50\%を境に，Vitric，Vitric-crystal, Crystal vitric, Crystal の 4つに分類した. すなわち, 図

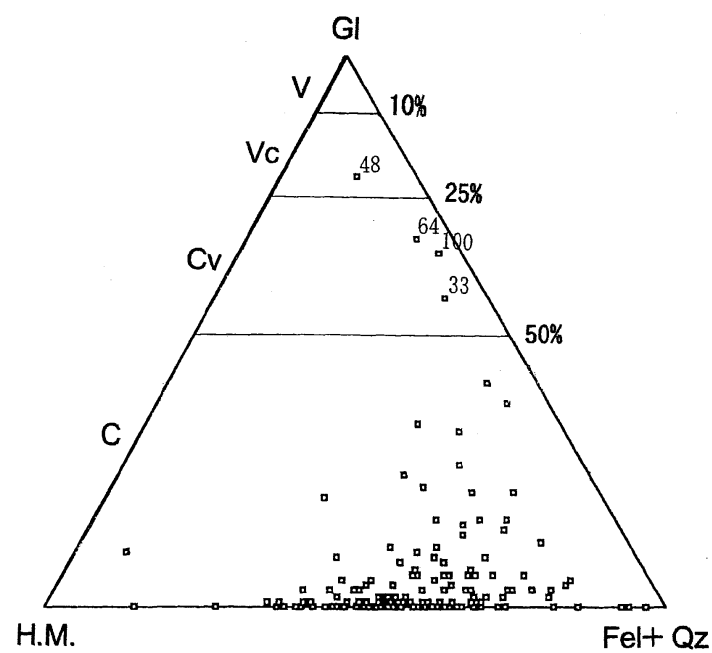

図 4 塩田層テフラの火山ガラス (Gl) 一重鉱物 (H.M.) 一軽鉱物 $(\mathrm{Fel}+\mathrm{Qz})$

V: Vitric Vc: Vitric-crystal Cv: Crystal-vitric C: Crystal 図中の数字はテフラ番号で Sd48, Sd64 など を示す. Cook (1965)による.

4 に示すように, テフラの約 $95 \%$ は火山ガラスの総量が 50\%以下の Crystal テフラであり, Vitric-crystal テフ ラは Sd48 のみ, Crystal vitric テフラは Sd33, Sd64, Sd 100 の 3 テフラである. Crystal テフラで火山ガラス含 有量が比較的多いあのは, Sd81, Sd117, Sd125, Sd126, Sd153がある.

火山ガラスの形状分類は吉川（1976）によった. 多く のテフラが多孔質型火山ガラスを主体とし，Sd64のみ 扁平型火山ガラスを少量含む. そのほかに分類した火山 ガラス (Oth) のほとんどが塊状の火山ガラスである.

軽鉱物のうち，石英を含むテフラは稀であるが, $\mathrm{Sd}$ 100 は $12 \%$ の石英を含む. 斜長石は累帯構造をむつあの が多く, 双晶がみられるものあある。

重鉱物組成では，多くのテフラか斜方輝石と単斜輝石 を主体とする. ただし，Sd22 から Sd38 までには角閃石 を多く含むテフラがあり，特に Sd22, Sd23, Sd24 は重鉱 物のほとんどが角閃石と不透明鉱物からなる. カンラン 石を含むテフラはなく，黒雲母を含むむのには 3 層のテ フラがあるが，黒雲母の含有比はいずれもごく小さい． 不透明鉱物の多くは磁鉄鉱である.

図 5 は，角閃石・斜方輝石・単斜輝石の含有比による テフラのタイプを示したあのである. すなわち，角閃石 に富むタイプ (A-type), 斜方輝石に富むタイプ (Otype), 単斜輝石に富む夕イプ (C-type)である. O-type 


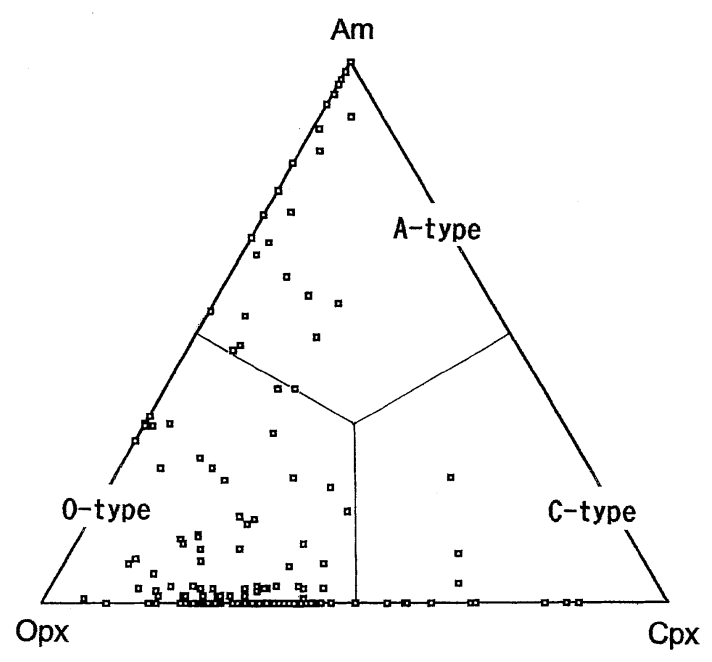

図 5 塩田層テフラの重鉱物組成ダイヤグラム $\mathrm{Am}$ : 角閃石 Opx : 斜方輝石 Cpx : 単斜輝石

が多く, 特に三角ダイヤグラムの Opx と Cpx を結ふ線 の近くに多く分布する. 重鉱物によるタイプと挾在層準 との関係は, 下部のむののほとんどがC-type に属し, その上位にわずかの A-type を挾み, 上部の多くはOtype である.

\section{Sd100 テフラの FT 年代}

Sd100 は，ほかのテフラに比べてジルコンの含有率が 著しく高く, ジルコンによる FT 年代を測定した. 測定 は, 株式会社京都フィッション・トラック（測定者: 檀 原 徹) に依頼し，ゼー夕較正法による結晶外部面 (ED 2)を用いた外部ディテクター法によって行った. 測定結 果は $2.1 \pm 0.5 \mathrm{Ma}$ である.

斎藤 (1988) は, 中津層群下部神沢層の 1 地点と本調 查地域 (図 2) の地点 $16,27,35,49$ 付近の 4 地点に打い て有孔虫の化石分析を行い, 古地磁気層序との組み合わ せから, 中津層群の堆積年代は約 $2.9 \mathrm{Ma}$ から $1.9 \mathrm{Ma}$ にわたるとした. Sd100 は中津層群の上部に位置するこ とから，本論で得た年代は斎藤 (1988) の示した値とよ く一致している.

\section{VII. ま と め}

1. 中津層群上部の塩田層に挾在する 190 層のテフラ について, それらの挾在層準, 岩相および記載岩石学的 性質を明らかにした。

2. 塩田層に挾在するテフラ Sd100 中のジルコン結
晶を用い, $\mathrm{FT}$ 年代 $2.1 \pm 0.5 \mathrm{Ma}$ を得た。

謝辞 本研究を進めるにあたり, 鳴門教育大学西村 宏教授，村田 守教授，小澤大成博士には，貴重なご意 見を賜った，調査にあたり，海老名市立海老名中学校瀬 尾為明先生, 吉川典章先生, 柏ケ谷中学校上田貴康先生 にご協力いただいた．記して感謝の意を表す．

\section{引用 文 献}

馬場勝良（1992）神奈川県北部中津層群の貝化石群. 瑞 浪市化石博物館研究報告, 19, 529-541， pl. 69-71.

Cook, E.F. (1965) Stratigraphy of Tertiary volcanic rocks in Eastern Nevada. Nevada Bureau of Mines Report, 11, 1-66.

長谷川善和 - 小泉明裕 - 岩本光雄 (1994) 上部鮮新統中 津層群産サル類頭蓋骨化石. 日本古生物学会第 143 回 例会講演予稿, 54 .

Ito, M. (1985) The Nakatsu Group : A Plio-Pleistocene transgressive nearshore to slope sequence embracing multiple slump scars in southeastern margin of the Kanto Mountains, Central Honshu, Japan. Jour. Geol. Soc. Japan, 91, 213-232.

小池 清・村井 勇 (1950）関東地方南部に扑凝灰 岩の基礎的研究 (I) -Tephrozoneについて一. 東京 大学立地研究所研究報告, 5, 22-26.

小泉明裕・長谷川善和（1988）神奈川県中津層群産ステ ゴドン象類の頭骨化石について. 日本古生物学会第 137 回例会講演予稿, 48.

中世古幸次郎 - 澤井 清 (1950) 中津層の化石有孔虫群 について. 地質学雑誌，55，205-210.

野田啓司・小澤大成・奥村 清（1999）神奈川県の上部 鮮新統中津層群からの含ザクロ石テフラ Mk19 の発 見之その意義. 第四紀研究，38，65-73.

岡田尚武（1987）南部フォッサマグナの海成層に関する 石灰質ナンノ化石の生層序と古環境. 化石, 43, 5-8. 奥村 清 ·上田貴康 - 小澤大成（1997）神奈川県相模川 沿岸に分布する中津層群の古生物学的研究. 鳴門教育 大学研究紀要, 12, 7-22.

Okumura, K. and Ueda, T. (1998) Molluscan fossils from the upper Pliocene Nakatsu Formation in the middle part of Sagami River, Kanagawa Prefecture, Japan. Bulletin of the Mizunami Museum, 26, 53-87.

斎藤常正（1988）関東地方におうる幾つかの哺乳類化石 
包含層の微化石年代. 昭和 62 (1987) 年度文部省科学 研究報告書「日本産海生哺乳類化石の研究」（代表者：

長谷川善和）: 140-148.

鈴木好一 (1932) 神奈川県厚木町北方の鮮新統 (其 1. 其
2). 地質学雑誌，39，49-70，97-132.

吉川周作（1976）大阪層群の火山灰層について．地質学 雑誌，82，497-515.

\title{
Tephrostratigraphy of the Shioda Formation of the Nakatsu Group along the Sagami River and Fission Track Age of Sd100 Tephra
}

\author{
Keiji Noda*1 and Kiyoshi Okumura*2
}

The tephrostratigraphic characters of the Shioda Formation of the Nakatsu Group, distributed along the Sagami River in central Japan, were described. This formation is $72 \mathrm{~m}$ in thickness and intercalates 190 tephra beds. According to the results of the tephrostrati- graphic research, several characteristic tephra beds were recognized in the formation. The tephra bed $\mathrm{Sd} 100$ is characterized by high ratio of quartz (12\%) and zircon. The fission track age measured for zircon grains of the Sd100 is $2.1 \pm 0.5 \mathrm{Ma}$.

*1 Oya Junior High School. 3535 Oya, Ebina, Kanagawa Pref., 243-0411 Japan. E-mail

*2 Faculty of Engineering, Tokushima Bunri University. Shido, Shido-cho, Okawa-gun Kagawa Pref., 7692193, Japan. 
付表 塩田層中テフラ層の記載岩石学的特徵

\begin{tabular}{|c|c|c|c|c|c|c|c|c|c|c|c|c|c|c|c|c|c|}
\hline Name of & Grade & Tephra facies & Thickness & & heral & comp & ositior & {$[\%]$} & & Shap & e of $\varepsilon$ & glass $\mathrm{s}$ & shard & [\%] & & Hea & vy $\mathrm{mi}$ \\
\hline tephra & & & {$[\mathrm{cm}]$} & $\mathrm{Gl}$ & $\mathrm{Qz}$ & Fel & R.F. & H.M. & $\mathrm{Ha}$ & $\mathrm{Hb}$ & $\mathrm{Ca}$ & $\mathrm{Cb}$ & $\mathrm{Ta}$ & $\mathrm{Tb}$ & Oth & $\mathrm{Bi}$ & Am \\
\hline Sdl & $\bar{A}$ & bla, g.g., sc & 10 & 0 & 0 & 38 & 40 & 22 & 0 & 0 & 0 & 0 & 0 & 0 & 0 & 0 & 3 \\
\hline $\mathrm{Sd} 2$ & A & bla, g.g., sc & 10 & 0 & 0 & 53 & 18 & 29 & 0 & 0 & 0 & 0 & 0 & 0 & 0 & 0 & 1 \\
\hline $\mathrm{Sd} 3$ & A & goma, co.sd. & 13 & 1 & 0 & 64 & 1 & 33 & 0 & 0 & 0 & 0 & 100 & 0 & 0 & 0 & 69 \\
\hline $\mathrm{Sd} 4$ & B & me.sd. & & 2 & 1 & 34 & 57 & 6 & 0 & 0 & 0 & 0 & 0 & 0 & 100 & 0 & 33 \\
\hline Sd5 & B & me.sd. & & 1 & 1 & 44 & 43 & 10 & 0 & 0 & 0 & 0 & 0 & 0 & 100 & 0 & 15 \\
\hline Sd6 & A & bla, g.g., $-5 \mathrm{~mm}, \mathrm{sc}, \mathrm{pu}$ & 5 & 0 & 0 & 15 & 77 & 8 & 0 & 0 & 0 & 0 & 0 & 0 & 0 & 0 & 0 \\
\hline $\mathrm{Sd} 7$ & A & bla, g.g., sc & 4 & 0 & 0 & 6 & 91 & 3 & 0 & 0 & 0 & 0 & 0 & 0 & 0 & 0 & 0 \\
\hline Sd8 & A & bla, g.g., $-5 \mathrm{~mm}, \mathrm{sc}, \mathrm{pu}$ & 2 & 0 & 0 & 37 & 50 & 13 & 0 & 0 & 0 & 0 & 0 & 0 & 0 & 0 & 0 \\
\hline Sd9 & A & bla, g.g., $-5 \mathrm{~mm}, \mathrm{sc}, \mathrm{pu}$ & 1 & 1 & 0 & 22 & 70 & 7 & 0 & 0 & 0 & 0 & 0 & 0 & 100 & 0 & 0 \\
\hline $\operatorname{Sd} 10$ & A & bla, g.g., sc & 1 & & & & & & & & & & & & & & \\
\hline Sd11 & B & me.sd. & & 1 & 0 & 21 & 70 & 7 & 0 & 0 & 0 & 0 & 67 & 33 & 0 & 0 & 0 \\
\hline $\mathrm{Sd} 12$ & A & me.sd. & 2 & 0 & 0 & 30 & 68 & 2 & 0 & 0 & 0 & 0 & 0 & 0 & 0 & 0 & 5 \\
\hline $\operatorname{Sd} 13$ & A & bla, g.g., $-5 \mathrm{~mm}, \mathrm{sc}, \mathrm{pu}$ & 2 & & & & & & & & & & & & & & \\
\hline Sd14(L) & A & bla, g.g., $-5 \mathrm{~mm}, \mathrm{sc}, \mathrm{pu}$ & 5 & 0 & 0 & 15 & 77 & 8 & 0 & 0 & 0 & 0 & 0 & 0 & 0 & 0 & 0 \\
\hline $\mathrm{Sd} 14(\mathrm{M})$ & A & & 4 & & & & & & & & & & & & & & \\
\hline Sd14(U) & A & bla, g.g., $-5 \mathrm{~mm}, \mathrm{sc}, \mathrm{pu}$ & 5 & & & & & & & & & & & & & & \\
\hline $\operatorname{Sd} 15$ & A & ora, p.g., $-10 \mathrm{~mm}, \mathrm{sc}, \mathrm{pu}$ & 7 & 0 & 0 & 20 & 66 & 14 & 0 & 0 & 0 & 0 & 0 & 0 & 0 & 0 & 2 \\
\hline $\operatorname{Sd} 16$ & A & ora, p.g., $-10 \mathrm{~mm}, \mathrm{sc}, \mathrm{pu}$ & 10 & 0 & 0 & 34 & 65 & 1 & 0 & 0 & 0 & 0 & 0 & 0 & 0 & 0 & 7 \\
\hline $\operatorname{Sd} 17$ & A & bro, me.sd. & 5 & 1 & 0 & 29 & 64 & 6 & 0 & 0 & 0 & 0 & 0 & 0 & 100 & 0 & 12 \\
\hline $\operatorname{Sd} 18$ & A & bla, g.g.,sc & 2 & 0 & 0 & 31 & 62 & 7 & 0 & 0 & 0 & 0 & 0 & 0 & 0 & 0 & 0 \\
\hline $\mathrm{Sd} 19$ & A & gra, g.g., $-5 \mathrm{~mm}, \mathrm{pu}, \mathrm{R} . \mathrm{F}$. & 12 & 0 & 0 & 36 & 45 & 20 & 0 & 0 & 0 & 0 & 0 & 0 & 0 & 0 & 90 \\
\hline $\operatorname{Sd} 20$ & A & ora, p.g., $-5 \mathrm{~mm}, \mathrm{sc}, \mathrm{pu}$ & 4 & 0 & 0 & 79 & 15 & 6 & 0 & 0 & 0 & 0 & 0 & 0 & 0 & 0 & 0 \\
\hline $\mathrm{Sd} 21$ & A & bro, p.g., $-5 \mathrm{~mm}, \mathrm{sc}, \mathrm{pu}$ & 5 & 0 & 0 & 36 & 58 & 6 & 0 & 0 & 0 & 0 & 0 & 0 & 0 & 0 & 0 \\
\hline Sd22(L) & A & goma, g.g., -5mm,pu & 18 & 19 & 0 & 34 & 2 & 44 & 0 & 0 & 0 & 0 & 100 & 0 & 0 & 0 & 89 \\
\hline $\operatorname{Sd} 22(U)$ & A & goma, g.g., $-5 \mathrm{~mm}, \mathrm{pu}$ & 19 & & & & & & & & & & & & & & \\
\hline $\mathrm{Sd} 23$ & A & whi, p.g., $-20 \mathrm{~mm}$,pu,R.F. & 3 & 0 & * & 48 & 16 & 36 & 0 & 0 & 0 & 0 & 0 & 0 & 0 & 0 & 72 \\
\hline $\mathrm{Sd} 24(\mathrm{~L})$ & A & whi, p.g., $-10 \mathrm{~mm}$,pu,R.F. & 7 & 1 & 0 & 49 & 20 & 30 & 0 & 0 & 0 & 0 & 100 & 0 & 0 & 0 & 81 \\
\hline $\mathrm{Sd} 24(\mathrm{M})$ & A & whi, p.g., $-10 \mathrm{~mm}$, pu,R.F. & 8 & & & & & & & & & & & & & & \\
\hline $\mathrm{Sd} 24(\mathrm{U})$ & A & whi, p.g., $-30 \mathrm{~mm}, \mathrm{pu}$, R.F. & 7 & & & & & & & & & & & & & & \\
\hline $\mathrm{Sd} 25$ & A & bla, g.g., $-5 \mathrm{~mm}, \mathrm{sc}$ & 3 & * & 0 & 43 & 54 & 3 & 0 & 0 & 0 & 0 & 0 & 0 & 100 & 0 & 9 \\
\hline $\mathrm{Sd} 26$ & A & whi, p.g., $-40 \mathrm{~mm}$,pu,R.F. & 8 & 7 & 0 & 44 & 24 & 25 & 0 & 0 & 0 & 0 & 91 & 9 & 0 & 0 & 91 \\
\hline $\mathrm{Sd} 27$ & A & whi, p.g., $-50 \mathrm{~mm}, \mathrm{pu}$, R.F. & 10 & 10 & 0 & 41 & 32 & 17 & 0 & 0 & 0 & 0 & 83 & 17 & 0 & 0 & 91 \\
\hline $\mathrm{Sd} 28$ & A & bla, p.g., $-5 \mathrm{~mm}, \mathrm{sc}$ & 8 & 2 & $*$ & 57 & 13 & 29 & 0 & 0 & 0 & 0 & 70 & 30 & 0 & 0 & 81 \\
\hline $\operatorname{Sd} 29$ & A & whi, p.g., $-10 \mathrm{~mm}, \mathrm{pu}$ & 2 & 0 & * & 53 & 14 & 33 & 0 & 0 & 0 & 0 & 0 & 0 & 0 & 0 & 55 \\
\hline $\mathrm{Sd} 30$ & B & g.g.,c.b.g., $-5 \mathrm{~mm}, \mathrm{pu}$ & 1 & 1 & 0 & 23 & 70 & 6 & 0 & 0 & 0 & 0 & 0 & 0 & 100 & 0 & 47 \\
\hline $\mathrm{Sd} 31$ & A & whi, p.g.,c.b.g., $-30 \mathrm{~mm}$,pu & 23 & 0 & 0 & 48 & 3 & 48 & 0 & 0 & 0 & 0 & 0 & 0 & 100 & 0 & 74 \\
\hline $\mathrm{Sd} 32$ & A & goma, v.c.sd.,pu & 16 & 0 & 0 & 61 & 2 & 37 & 0 & 0 & 0 & 0 & 100 & 0 & 0 & 0 & 68 \\
\hline $\mathrm{Sd} 33$ & A & whi, co.sd.,pu & 2 & 47 & 9 & 22 & 17 & 6 & 0 & 0 & 24 & 37 & 4 & 11 & 24 & 0 & 1 \\
\hline $\mathrm{Sd} 34$ & A & gra, v.c.sd., $-5 \mathrm{~mm}$,pu & 10 & 1 & 0 & 55 & 3 & 42 & 0 & 0 & 0 & 0 & 100 & 0 & 0 & 0 & 64 \\
\hline Sd35 & $\mathrm{C}$ & $-50 \mathrm{~mm}, \mathrm{pu}, \mathrm{R} . \mathrm{F}$. & 30 & 9 & 0 & 42 & 37 & 12 & 0 & 0 & 0 & 0 & 82 & 18 & 0 & 0 & 20 \\
\hline $\mathrm{Sd} 36$ & A & goma, v.c.sd. & 2 & 0 & 0 & 59 & 1 & 40 & 0 & 0 & 0 & 0 & 0 & 0 & 0 & 0 & 85 \\
\hline $\mathrm{Sd} 37$ & A & whi, p.g., $-10 \mathrm{~mm}, \mathrm{pu}$ & 7 & 4 & 0 & 37 & 26 & 33 & 0 & 0 & 0 & 0 & 100 & 0 & 0 & 0 & 22 \\
\hline $\mathrm{Sd} 38$ & A & gra, p.g.,c.b.g., $-10 \mathrm{~mm}$, pu,R.F & 10 & 1 & * & 29 & 11 & 59 & 0 & 0 & 0 & 0 & 100 & 0 & 0 & 0 & 56 \\
\hline Sd39 & $\mathrm{C}$ & whi, p.g.,c.b.g., $-20 \mathrm{~mm}$, pu, $(-5 \mathrm{~mm}$, R.F. $)$ & 8 & 2 & 0 & 34 & 31 & 33 & 0 & 0 & 0 & 0 & 67 & 0 & 33 & 0 & 2 \\
\hline $\mathrm{Sd} 40$ & A & whi, p.g., $-10 \mathrm{~mm}, \mathrm{pu}$ & 4 & 1 & 0 & 62 & 0 & 36 & 0 & 0 & 0 & 0 & 100 & 0 & 0 & 0 & 8 \\
\hline $\mathrm{Sd} 41$ & A & goma, p.g.,c.b.g., $-10 \mathrm{~mm}, \mathrm{pu}$ & 5 & 1 & 0 & 62 & 2 & 35 & 0 & 0 & 0 & 0 & 50 & 50 & 0 & 0 & 0 \\
\hline $\mathrm{Sd} 42$ & A & goma, g.g., $-10 \mathrm{~mm}, \mathrm{pu}$ & 3 & 0 & 0 & 53 & 1 & 46 & 0 & 0 & 0 & 0 & 0 & 0 & 0 & 0 & 0 \\
\hline $\operatorname{Sd} 43$ & A & whi, p.g., $-10 \mathrm{~mm}$,pu,R.F. & 4 & * & 0 & 46 & 2 & 52 & 0 & 0 & 0 & 0 & 100 & 0 & 0 & 0 & 0 \\
\hline $\mathrm{Sd} 44$ & B & whi, p.g., $-10 \mathrm{~mm}, \mathrm{pu}$ & & 1 & 0 & 52 & 6 & 40 & 0 & 0 & 0 & 0 & 60 & 40 & 0 & 0 & 0 \\
\hline $\mathrm{Sd} 45$ & A & goma, p.g.,c.b.g., $-10 \mathrm{~mm}, \mathrm{pu}$ & 13 & 0 & 0 & 37 & 1 & 62 & 0 & 0 & 0 & 0 & 0 & 0 & 0 & 0 & 0 \\
\hline $\mathrm{Sd} 46$ & B & whi, p.g., $-10 \mathrm{~mm}$, pu & & 1 & 0 & 61 & 2 & 35 & 0 & 0 & 0 & 0 & 89 & 11 & 0 & 0 & 0 \\
\hline $\mathrm{Sd} 47$ & A & whi, p.g.,c.b.g., $-20 \mathrm{~mm}, \mathrm{pu}$ & 11 & 1 & 0 & 46 & 4 & 49 & 0 & 0 & 0 & 0 & 80 & 20 & 0 & 0 & 0 \\
\hline $\operatorname{Sd} 48$ & B & whi, me.sd.,tuff.sd & & 64 & 0 & 10 & 17 & 8 & 0 & 0 & 6 & 10 & 24 & 26 & 34 & 0 & 0 \\
\hline Sd49 & A & goma, g.g.,c.b.g. & 11 & 0 & 0 & 61 & 2 & 38 & 0 & 0 & 0 & 0 & 0 & 0 & 0 & 0 & 0 \\
\hline Sd50 & A & goma, g.g., $-10 \mathrm{~mm}$,pu & 24 & 0 & 0 & 55 & 1 & 45 & 0 & 0 & 0 & 0 & 0 & 0 & 0 & 0 & 0 \\
\hline Sd51 & A & whi, p.g. & 2 & 1 & 0 & 34 & 39 & 26 & 0 & 0 & 0 & 0 & 100 & 0 & 0 & 0 & 0 \\
\hline Sd52 & A & goma, v.c.sd. & 14 & 0 & 0 & 52 & 1 & 48 & 0 & 0 & 0 & 0 & 0 & 0 & 0 & 0 & 0 \\
\hline Sd53 & A & goma, p.g., $-10 \mathrm{~mm}, \mathrm{pu}$ & 10 & 1 & 0 & 48 & 0 & 51 & 0 & 0 & 0 & 0 & 80 & 20 & 0 & 0 & 0 \\
\hline Sd54 & A & whi, p.g., $-20 \mathrm{~mm}, \mathrm{pu}$ & 7 & 0 & 0 & 72 & 2 & 26 & 0 & 0 & 0 & 0 & 0 & 0 & 0 & 0 & 0 \\
\hline Sd55(L) & A & goma, g.g.,c.b.g. & 4 & 0 & 0 & 59 & 2 & 39 & 0 & 0 & 0 & 0 & 0 & 0 & 0 & 0 & 0 \\
\hline Sd55(M) & A & & 1 & & & & & & & & & & & & & & \\
\hline $\mathrm{Sd} 55(\mathrm{U})$ & A & goma, p.g.,c.b.g. & 5 & 0 & 0 & 50 & 0 & 50 & 0 & 0 & 0 & 0 & 0 & 0 & 0 & 0 & 0 \\
\hline Sd56 & A & whi, p.g.,c.b.g., $-10 \mathrm{~mm}$,pu & 5 & 0 & 0 & 56 & 1 & 43 & 0 & 0 & 0 & 0 & 0 & 0 & 0 & 0 & 0 \\
\hline Sd57 & B & goma, p.g. & & 2 & 0 & 47 & 13 & 39 & 0 & 0 & 0 & 0 & 100 & 0 & 0 & 0 & 0 \\
\hline 158 & A & whi, p.g., $-20 \mathrm{~mm}, \mathrm{pu}$ & 18 & * & 0 & 48 & 2 & 50 & 0 & 0 & 0 & 0 & 100 & 0 & 0 & 0 & 0 \\
\hline $\mathrm{Sd}$ & A & goma, g.g. & 5 & * & 0 & 43 & 3 & 53 & 0 & 0 & 0 & 100 & 0 & 0 & 0 & 0 & 0 \\
\hline Sd60 & A & yed, p.g.,c.b.g., $-10 \mathrm{~mm}$, & 5 & 0 & 0 & 42 & 1 & 56 & 0 & 0 & 0 & 0 & 0 & 0 & 0 & 0 & 43 \\
\hline Sd61 & A & ora, p.g.,c.b.g., $-5 \mathrm{~mm}$,pu ,R.F. & 6 & 0 & 0 & 54 & 12 & 34 & 0 & 0 & 0 & 0 & 0 & 0 & 0 & 0 & 46 \\
\hline Sd62 & A & goma, p.g. $-50 \mathrm{~mm}, \mathrm{pu}, \mathrm{R} . \mathrm{F}$. & 26 & 2 & 0 & 55 & 4 & 39 & 0 & 0 & 0 & 0 & 0 & 64 & 36 & 0 & 61 \\
\hline Sd63 & A & whi, p.g., $-30 \mathrm{~mm}, \mathrm{pu}$ & 6 & * & 0 & 65 & 1 & 33 & 0 & 0 & 0 & 0 & 0 & 100 & 0 & 0 & 19 \\
\hline Sd64 & A & whi, co.sd. & 10 & 65 & 0 & 26 & 2 & 6 & 0 & 2 & 9 & 13 & 16 & 27 & 33 & 0 & 25 \\
\hline Sd65 & A & whi, v.c.sd. & 3 & 3 & 0 & 51 & 19 & 26 & 0 & 0 & 0 & 0 & 50 & 0 & 50 & 0 & 18 \\
\hline Sd66 & A & whi, p.g., $-20 \mathrm{~mm}$,pu,R.F. & 9 & * & 0 & 69 & 1 & 31 & 0 & 0 & 0 & 0 & 0 & 33 & 67 & 0 & 13 \\
\hline Sd67 & $\mathrm{C}$ & whi, p.g., $-20 \mathrm{~mm}, \mathrm{pu}$ & 25 & 0 & 0 & 54 & 23 & 23 & 0 & 0 & 0 & 0 & 0 & 0 & 0 & 0 & 0 \\
\hline Sd68 & A & whi, g.g., $-5 \mathrm{~mm}, \mathrm{pu}$ & 8 & 0 & 0 & 54 & 14 & 32 & 0 & 0 & 0 & 0 & 0 & 0 & 0 & 0 & 0 \\
\hline Sd69 & A & gra, co.sd. & 5 & 0 & 0 & 58 & 4 & 37 & 0 & 0 & 0 & 0 & 0 & 0 & 0 & 0 & 0 \\
\hline Sd70 & A & whi, p.g.,c.b.g., $-10 \mathrm{~mm}, \mathrm{pu}$ & 7 & * & 0 & 47 & 1 & 52 & 0 & 0 & 0 & 0 & 0 & 100 & 0 & 0 & 0 \\
\hline Sd71 & C & $-30 \mathrm{~mm}, \mathrm{pu}$ & 4 & 1 & 0 & 48 & 17 & 34 & 0 & 0 & 0 & 0 & 100 & 0 & 0 & 0 & 0 \\
\hline Sd72 & $\mathrm{C}$ & $-50 \mathrm{~mm}, \mathrm{pu}, \mathrm{R} . \mathrm{F}$. & 20 & 0 & 0 & 41 & 39 & 21 & 0 & 0 & 0 & 0 & 0 & 0 & 0 & 0 & 2 \\
\hline
\end{tabular}

* :less $1 \%$, whi:white, bla:black, ora:orange, bro:brown, yel:yellow, gra:gray, bei:beige, goma:goma-shio-like, g.g :

c.b.g.:Tephra of conspicuous black grains, sd:sand, sc:scoria, pu:pumice, v:very, c:coarse, me:medium, fi:fine, ( ):including, R.F.: rock fragment,

Tephra of Shape of glass shard: after Yoshikawa (1976)

Gl:glass, Qz:quartz, Fel:feldspars, H.M.: heavy minerals, Bi:biotite, Am:amphiboles, Opx:orthopyroxenes, Cpx:clinopyroxenes, Opq:opaque mineral 


\begin{tabular}{|c|c|c|c|c|c|c|c|c|c|c|c|c|c|c|c|c|}
\hline Name of & Grade & Tephra facies & Thickness & & heral & comp & ositio & $\mathrm{n}[\%]$ & & Shap & e of & glass & shard & {$[\%]$} & & $\mathrm{He}$ \\
\hline tephra & & & {$[\mathrm{cm}]$} & Gl & $\mathrm{Qz}$ & Fel & R.F. & H.M. & $\mathrm{Ha}$ & $\mathrm{Hb}$ & $\mathrm{Ca}$ & $\mathrm{Cb}$ & Ta & $\mathrm{Tb}$ & Oth & $\mathrm{Bi}$ \\
\hline Sd73 & A & goma, g.g. & 8 & 0 & 0 & 52 & 7 & 41 & 0 & 0 & 0 & 0 & 100 & 0 & 0 & 0 \\
\hline $\mathrm{Sd} 74$ & A & whi, co.sd. & 2 & 9 & 0 & 28 & 58 & 6 & 0 & 0 & 19 & 6 & 31 & 25 & 19 & 0 \\
\hline Sd75 & $\mathrm{C}$ & p.g., $-30 \mathrm{~mm}$, pu & 10 & 1 & 0 & 40 & 30 & 29 & 0 & 0 & 0 & 0 & 100 & 0 & 0 & 0 \\
\hline Sd76 & $\mathrm{C}$ & g.g., $-5 \mathrm{~mm}, \mathrm{pu}$ & 1 & 2 & 0 & 40 & 51 & 7 & 0 & 0 & 25 & 0 & 50 & 25 & 0 & 0 \\
\hline Sd77 & A & gra, p.g.,c.b.g., $-20 \mathrm{~mm}, \mathrm{pu}$, & 3 & 0 & 0 & 58 & 3 & 39 & 0 & 0 & 0 & 0 & 0 & 0 & 0 & 0 \\
\hline $\mathrm{Sd} 78$ & A & goma, p.g., $-5 \mathrm{~mm}, \mathrm{pu}$ & 15 & 0 & 0 & 50 & 2 & 48 & 0 & 0 & 0 & 0 & 0 & 0 & 0 & 0 \\
\hline Sd79 & A & goma, g.g., $-10 \mathrm{~mm}$,pu & 17 & 0 & 0 & 47 & 4 & 50 & 0 & 0 & 0 & 0 & 0 & 0 & 0 & 0 \\
\hline $\mathrm{Sd} 80$ & A & yel, p.g., $-20 \mathrm{~mm}, \mathrm{pu}$ & 20 & 2 & $*$ & 57 & 6 & 34 & 0 & 0 & 0 & 0 & 0 & 100 & 0 & 0 \\
\hline $\operatorname{Sd} 81$ & A & whi, p.g., $-10 \mathrm{~mm}, \mathrm{pu}$ & 3 & 26 & 0 & 33 & 37 & 5 & 0 & 0 & 0 & 6 & 64 & 27 & 3 & 0 \\
\hline $\mathrm{Sd} 82$ & A & bei, p.g., $-10 \mathrm{~mm}$,pu,R.F. & 11 & 0 & 0 & 13 & 6 & 80 & 0 & 0 & 0 & 0 & 0 & 0 & 0 & 0 \\
\hline Sd83 & A & goma, g.g.,pu & 3 & 24 & * & 47 & 16 & 13 & 0 & 0 & 11 & 4 & 72 & 13 & 0 & 0 \\
\hline Sd84 & A & bei, g.g., $-5 \mathrm{~mm}$,pu,R.F. & 10 & 0 & 0 & 48 & 14 & 37 & 0 & 0 & 0 & 0 & 0 & 0 & 0 & 0 \\
\hline $\mathrm{Sd} 85(\mathrm{~L})$ & A & whi, p.g., $-20 \mathrm{~mm}, \mathrm{pu}$ & 20 & 0 & 0 & 37 & 46 & 17 & 0 & 0 & 0 & 0 & 0 & 0 & 0 & 0 \\
\hline Sd85(M) & A & whi-gra, p.g., $-20 \mathrm{~mm}, \mathrm{pu}$ & 12 & & & & & & & & & & & & & \\
\hline $\mathrm{Sd} 85(\mathrm{U})$ & $\mathrm{C}$ & gra, p.g., $-20 \mathrm{~mm}, \mathrm{pu}$ & 10 & & & & & & & & & & & & & \\
\hline Sd86 & $\mathrm{C}$ & p.g., $-20 \mathrm{~mm}, \mathrm{pu}$ & 4 & & & & & & & & & & & & & \\
\hline Sd87 & A & whi, p.g., $-10 \mathrm{~mm}$, pu,R.F. & 12 & 0 & 0 & 50 & 3 & 46 & 0 & 0 & 0 & 0 & 0 & 0 & 0 & 0 \\
\hline $\operatorname{Sd} 88$ & C & goma, p.g.,pu & 2 & 0 & 0 & 39 & 6 & 55 & 0 & 0 & 0 & 0 & 0 & 0 & 0 & 0 \\
\hline Sd89 & A & whi, p.g., $-10 \mathrm{~mm}$,pu,R.F. & 10 & 0 & 0 & 51 & 8 & 40 & 0 & 0 & 0 & 0 & 0 & 0 & 0 & 0 \\
\hline Sd90 & $\mathrm{C}$ & ora, p.g., $-10 \mathrm{~mm}, \mathrm{pu}$ & 3 & * & 0 & 39 & 33 & 27 & 0 & 0 & 0 & 0 & 100 & 0 & 0 & 0 \\
\hline Sd91 & A & whi, p.g., $-10 \mathrm{~mm}, \mathrm{pu}$ & 7 & 0 & 0 & 52 & 20 & 27 & 0 & 0 & 0 & 0 & 0 & 0 & 0 & 0 \\
\hline Sd92 & A & ora, p.g., $-30 \mathrm{~mm}, \mathrm{pu}, \mathrm{R} . \mathrm{F}$. & 30 & 0 & 0 & 62 & 9 & 28 & 0 & 0 & 0 & 0 & 0 & 0 & 0 & 0 \\
\hline Sd93 & A & whi, p.g., $-20 \mathrm{~mm}, \mathrm{pu}$ & 8 & 4 & 0 & 47 & 28 & 21 & 0 & 0 & 0 & 0 & 88 & 13 & 0 & 0 \\
\hline Sd94 & A & bei, p.g., $-20 \mathrm{~mm}, \mathrm{pu}$, R.F. & 5 & 0 & 0 & 48 & 5 & 46 & 0 & 0 & 0 & 0 & 0 & 0 & 0 & 0 \\
\hline Sd95 & $\mathrm{C}$ & $-20 \mathrm{~mm}, \mathrm{pu}, \mathrm{R} . \mathrm{F}$ & 4 & 10 & 0 & 34 & 37 & 18 & 0 & 0 & 0 & 0 & 79 & 7 & 14 & 0 \\
\hline Sd96 & A & gra, p.g., $-5 \mathrm{~mm}, \mathrm{pu}$ & 10 & 2 & 0 & 45 & 23 & 29 & 0 & 0 & 0 & 0 & 79 & 21 & 0 & 0 \\
\hline $\begin{array}{l}\operatorname{Sd} 97 \\
\text { Sd98 }\end{array}$ & $\begin{array}{l}\mathrm{A} \\
\mathrm{B}\end{array}$ & $\begin{array}{l}\text { bei, p.g., }-20 \mathrm{~mm} \text {,pu,R.F. } \\
\text { yel, g.g. }\end{array}$ & 6 & $*$ & 0 & 46 & 19 & 35 & 0 & 0 & 0 & 0 & 100 & 0 & 0 & 0 \\
\hline Sd99 & A & gra, p.g., $-30 \mathrm{~mm}, \mathrm{pu}$, R.F. & 12 & 1 & 0 & 46 & 16 & 37 & 0 & 0 & 0 & 0 & 100 & 0 & 0 & 0 \\
\hline $\mathrm{Sd} 100$ (L) & A & whi, v.c.sd.,pu & 21 & 64 & 12 & 20 & 0 & 4 & 0 & 0 & 14 & 10 & 36 & 33 & 7 & 4 \\
\hline Sd100(M & A & whi, g.g.pu & 6 & & & & & & & & & & & & & \\
\hline Sd100(U) & A & bei, g.g.,c.b.g.,pu & 3 & & & & & & & & & & & & & \\
\hline Sd101 & A & goma, g.g.,pu & 8 & 0 & 0 & 39 & 3 & 58 & 0 & 0 & 0 & 0 & 0 & 0 & 0 & 0 \\
\hline Sd102 & A & goma, g.g., $-5 \mathrm{~mm}, \mathrm{pu}$ & 8 & 1 & 0 & 52 & 3 & 44 & 0 & 0 & 0 & 0 & 100 & 0 & 0 & 0 \\
\hline Sd103 & $\mathrm{C}$ & bei, p.g., $-30 \mathrm{~mm}, \mathrm{pu}$ & 14 & 4 & 0 & 35 & 46 & 15 & 0 & 0 & 0 & 0 & 67 & 22 & 11 & 0 \\
\hline Sd104 & A & bei, p.g., $-10 \mathrm{~mm}$, pu & 5 & 0 & 0 & 45 & 5 & 50 & 0 & 0 & 0 & 0 & 0 & 0 & 0 & 0 \\
\hline Sd105 & A & whi, p.g., $-10 \mathrm{~mm}, \mathrm{pu}$ & 5 & 7 & 0 & 34 & 20 & 39 & 0 & 0 & 0 & 0 & 80 & 20 & 0 & 0 \\
\hline Sd106 & $\mathrm{C}$ & p.g., $-5 \mathrm{~mm}, \mathrm{pu}$ & 9 & 9 & 0 & 36 & 42 & 13 & 0 & 0 & 0 & 0 & 87 & 13 & 0 & 0 \\
\hline Sd107 & A & whi, g.g.,pu & 4 & 1 & 0 & 54 & 7 & 38 & 0 & 0 & 0 & 0 & 100 & 0 & 0 & 0 \\
\hline Sd108 & A & gra, v.c.sd. & 3 & 0 & 0 & 43 & 3 & 53 & 0 & 0 & 0 & 0 & 0 & 0 & 0 & 0 \\
\hline Sd109 & A & bla, g.g., $-5 \mathrm{~mm}$,sc & 4 & 2 & 0 & 20 & 57 & 22 & 0 & 0 & 0 & 0 & 57 & 14 & 29 & 0 \\
\hline $\mathrm{Sd} 110(\mathrm{~L})$ & A & whi, p.g., $-20 \mathrm{~mm}$, pu,R.F. & 7 & 1 & 0 & 54 & 9 & 35 & 0 & 0 & 0 & 0 & 67 & 33 & 0 & 0 \\
\hline $\mathrm{Sd} 110(\mathrm{U})$ & $\mathrm{C}$ & whi, p.g., $-20 \mathrm{~mm}$, pu,R.F. & 13 & & & & & & & & & & & & & \\
\hline Sd111(L) & A & whi, p.g., $-20 \mathrm{~mm}$,pu,R.F. & 4 & 2 & 0 & 60 & 17 & 21 & 0 & 0 & 0 & 0 & 85 & 15 & 0 & 0 \\
\hline $\mathrm{Sd} 111(\mathrm{U})$ & $\mathrm{C}$ & whi, p.g., $-50 \mathrm{~mm}$,pu,R.F. & 5 & & & & & & & & & & & & & \\
\hline $\mathrm{Sd} 112$ & A & whi, p.g., $-10 \mathrm{~mm}$, pu,R.F. & 5 & 1 & 0 & 49 & 4 & 46 & 0 & 0 & 0 & 0 & 100 & 0 & 0 & 0 \\
\hline Sd113 & A & whi, p.g., $-5 \mathrm{~mm}$, pu,R.F. & 4 & 4 & 0 & 45 & 8 & 42 & 0 & 0 & 0 & 0 & 83 & 17 & 0 & 0 \\
\hline $\operatorname{Sd} 114$ & $\mathrm{C}$ & whi, p.g., $-5 \mathrm{~mm}$, pu,R.F. & 3 & 2 & 0 & 46 & 14 & 37 & 0 & 0 & 0 & 0 & 83 & 17 & 0 & 0 \\
\hline Sd115 & A. & whi-gra, p.g., $-20 \mathrm{~mm}$, pu,R.F. & 10 & 2 & 0 & 43 & 18 & 37 & 0 & 0 & 0 & 0 & 100 & 0 & 0 & 0 \\
\hline Sd116 & A & yel, p.g., $-10 \mathrm{~mm}, \mathrm{pu}$ & 3 & 4 & 0 & 52 & 14 & 30 & 0 & 0 & 0 & 0 & 100 & 0 & 0 & 0 \\
\hline Sd117 & B & yel, g.g.,pu & & 22 & 0 & 46 & 15 & 17 & 0 & 0 & 0 & 0 & 95 & 5 & 0 & 0 \\
\hline Sd118 & A & goma, g.g.,pu & 3 & 3 & 0 & 39 & 2 & 55 & 0 & 0 & 0 & 0 & 93 & 7 & 0 & 0 \\
\hline Sd119 & A & goma, g.g.,pu & 6 & 2 & 0 & 46 & 2 & 51 & 0 & 0 & 0 & 0 & 82 & 18 & 0 & 0 \\
\hline $\mathrm{Sd} 120$ & A & ora, p.g., $-10 \mathrm{~mm}, \mathrm{pu}$, R.F. & 8 & 9 & 0 & 47 & 14 & 30 & 0 & 0 & 0 & 0 & 100 & 0 & 0 & 0 \\
\hline Sd121 & A & ora, g.g., $-10 \mathrm{~mm}, \mathrm{pu}$, R.F. & 7 & 2 & 0 & 43 & 7 & 49 & 0 & 0 & 0 & 0 & 83 & 17 & 0 & 0 \\
\hline Sd122 & B & v.c.sd.,pu & & 12 & 0 & 55 & 8 & 24 & 0 & 0 & 0 & 4 & 57 & 13 & 26 & 0 \\
\hline Sd123 & A & whi, g.g., $-10 \mathrm{~mm}, \mathrm{pu}$ & 5 & $*$ & 0 & 42 & 34 & 23 & 0 & 0 & 0 & 0 & 100 & 0 & 0 & 0 \\
\hline Sd124 & B & gra, v.c.sd.,pu & & 1 & 0 & 45 & 12 & 43 & 0 & 0 & 0 & 0 & 75 & 25 & 0 & 0 \\
\hline Sd125 & A & goma, g.g.pu & 6 & 32 & 4 & 45 & 13 & 6 & 0 & 0 & 14 & 18 & 11 & 43 & 14 & 0 \\
\hline $\mid \mathrm{Sd} 126(\mathrm{~L})$ & A & whi, g.g. $-10 \mathrm{~mm}, \mathrm{pu}$ & 16 & 31 & 0 & 50 & 3 & 17 & 0 & 0 & 0 & 0 & 98 & 2 & 0 & 0 \\
\hline $\mathrm{Sd} 126(\mathrm{U})$ & $\mathrm{C}$ & ora, p.g., $-20 \mathrm{~mm}, \mathrm{pu}$ & 22 & & & & & & & & & & & & & \\
\hline $\mathrm{Sd} 127(\mathrm{~L})$ & A & goma, g.g.,pu & 10 & 6 & 0 & 57 & 6 & 31 & 0 & 0 & 0 & 0 & 91 & 9 & 0 & 0 \\
\hline Sd127(M & A & & 2 & & & & & & & & & & & & & \\
\hline $\mathrm{Sd} 127(\mathrm{U})$ & A & goma, g.g., $-5 \mathrm{~mm}, \mathrm{pu}, \mathrm{R} . \mathrm{F}$. & 5 & & & & & & & & & & & & & \\
\hline Sd128 & A & whi, g.g.,c.b.g., $-10 \mathrm{~mm}, \mathrm{pu}$ & 4 & 0 & 0 & 56 & 20 & 25 & 0 & 0 & 0 & 0 & 0 & 0 & 0 & 0 \\
\hline Sd129 & $\mathrm{C}$ & p.g., $-10 \mathrm{~mm}, \mathrm{pu}$ & 5 & 0 & 0 & 55 & 10 & 35 & 0 & 0 & 0 & 0 & 0 & 0 & 0 & 0 \\
\hline Sd130 & $\mathrm{C}$ & p.g., $-20 \mathrm{~mm}$, pu & 10 & 1 & 0 & 46 & 30 & 24 & 0 & 0 & 0 & 0 & 100 & 0 & 0 & 0 \\
\hline $\mathrm{Sd} 131$ & A & whi, g.g.,c.b.g., $-10 \mathrm{~mm}$,pu & 4 & 1 & 0 & 40 & 4 & 55 & 0 & 0 & 0 & 0 & 100 & 0 & 0 & 0 \\
\hline Sd132(L) & A & whi, g.g., $-10 \mathrm{~mm}, \mathrm{pu}$ & 9 & 1 & 0 & 34 & 3 & 63 & 0 & 0 & 0 & 0 & 100 & 0 & 0 & 0 \\
\hline Sd132(U) & $\mathrm{C}$ & whi, p.g., $-10 \mathrm{~mm}, \mathrm{pu}$, R.F. & 3 & & & & & & & & & & & & & \\
\hline Sd133 & A & yel, p.g., $-20 \mathrm{~mm}$,pu & 7 & * & 0 & 39 & 1 & 59 & 0 & 0 & 0 & 0 & 100 & 0 & 0 & 0 \\
\hline Sd134 & $\mathrm{C}$ & yel, p.g., $-5 \mathrm{~mm}, \mathrm{pu}$ & 3 & & & & & & & & & & & & & \\
\hline Sd135 & A & goma, co.sd.,pu & 4 & 1 & 0 & 56 & 4 & 40 & 0 & 0 & 0 & 0 & 67 & 33 & 0 & 0 \\
\hline Sd136 & A & goma, v.c.sd.,pu & 4 & 8 & 0 & 62 & 8 & 23 & 0 & 0 & 0 & 0 & 91 & 9 & 0 & 0 \\
\hline Sd137 & A & whi, p.g., $-20 \mathrm{~mm}, \mathrm{pu}$ & 8 & 0 & 0 & 61 & 5 & 34 & 0 & 0 & 0 & 0 & 0 & 0 & 0 & 0 \\
\hline Sd138 & $\mathrm{C}$ & whi, p.g., $-20 \mathrm{~mm}$,pu & 10 & 4 & 0 & 47 & 32 & 17 & 0 & 0 & 0 & 0 & 100 & 0 & 0 & 0 \\
\hline Sd139 & A & ora, p.g., $-10 \mathrm{~mm}, \mathrm{pu}$ & 14 & 6 & 0 & 48 & 14 & 32 & 0 & 0 & 0 & 0 & 100 & 0 & 0 & 0 \\
\hline Sd140 & $\mathrm{C}$ & ora, p.g., $-20 \mathrm{~mm}, \mathrm{pu}$ & 5 & 2 & 0 & 51 & 24 & 23 & 0 & 0 & 0 & 0 & 67 & 33 & 0 & 0 \\
\hline Sd141 & $\mathrm{C}$ & ora, p.g., $-30 \mathrm{~mm}, \mathrm{pu}$ & 6 & 1 & 0 & 50 & 7 & 42 & 0 & 0 & 0 & 0 & 67 & 33 & 0 & 0 \\
\hline Sd142 & A & whi, v.c.sd. & 4 & 9 & 0 & 7 & 14 & 70 & 0 & 0 & 0 & 0 & 38 & 43 & 19 & 0 \\
\hline Sd143 & A & bei, g.g., $-10 \mathrm{~mm}, \mathrm{pu}$, R.F. & 10 & 8 & 0 & 52 & 1 & 39 & 0 & 0 & 0 & 0 & 100 & 0 & 0 & 0 \\
\hline
\end{tabular}




\begin{tabular}{|c|c|c|c|c|c|c|c|c|c|c|c|c|c|c|c|c|c|c|c|c|c|}
\hline Name of & Grade & Tephra facies & Thickness & & neral & comp & osition & $n[\%]$ & & Shap & e of $\varepsilon$ & jlass & shard & & & Hea & $\mathrm{vy} \mathrm{mi}$ & ineral & comp & ositic & on[\%] \\
\hline tephra & & & {$[\mathrm{cm}]$} & $\mathrm{Gl}$ & $\mathrm{Qz}$ & $\mathrm{Fel}$ & R.F. & H.M. & $\mathrm{Ha}$ & $\mathrm{Hb}$ & $\mathrm{Ca}$ & $\mathrm{Cb}$ & $\mathrm{Ta}$ & $\mathrm{Tb}$ & Oth & $\mathrm{Bi}$ & Am & Opx & $\mathrm{Cpx}$ & $\mathrm{Zr}$ & Opq \\
\hline Sd144 & $\mathrm{C}$ & p.g., $-10 \mathrm{~mm}, \mathrm{pu}$ & 3 & 1 & 0 & 47 & 13 & 40 & 0 & 0 & 0 & 0 & 75 & 0 & 25 & 0 & 0 & 56 & 20 & 0 & 23 \\
\hline Sd145 & A & whi, p.g.,c.b.g., $-20 \mathrm{~mm}$,pu,R.F. & 3 & 0 & 0 & 33 & 13 & 54 & 0 & 0 & 0 & 0 & 0 & 0 & 0 & 0 & 0 & 39 & 21 & 0 & 40 \\
\hline Sd146 & A & goma, p.g., -20mm,pu,R.F. & 5 & 6 & 0 & 56 & 2 & 36 & 0 & 0 & 0 & 0 & 100 & 0 & 0 & 0 & 0 & 45 & 30 & 0 & 25 \\
\hline Sd147 & A & goma, g.g.,c.b.g.,pu & 8 & $*$ & 0 & 47 & 2 & 50 & 0 & 0 & 0 & 0 & 100 & 0 & 0 & 0 & 0 & 53 & 34 & 0 & 13 \\
\hline Sd148 & A & yel, p.g.,c.b.g., $-10 \mathrm{~mm}$,pu & 5 & 3 & 0 & 46 & 16 & 36 & 0 & 0 & 0 & 0 & 88 & 6 & 6 & 0 & 0 & 50 & 35 & 0 & 16 \\
\hline Sd149 & A & goma, v.c.sd. & 5 & * & * & 35 & 4 & 61 & 0 & 0 & 0 & 0 & 100 & 0 & 0 & 0 & 0 & 33 & 17 & 0 & 50 \\
\hline Sd150 & A & goma, g.g., $-5 \mathrm{~mm}, \mathrm{pu}$ & 3 & 2 & 0 & 48 & 28 & 22 & 0 & 0 & 0 & 0 & 33 & 33 & 33 & 0 & 53 & 27 & 2 & 0 & 18 \\
\hline Sd151 & A & $-10 \mathrm{~mm}, \mathrm{pu}$ & 13 & 1 & 0 & 42 & 40 & 17 & 0 & 0 & 0 & 0 & 67 & 33 & 0 & 0 & 28 & 42 & 19 & 0 & 11 \\
\hline Sd152 & $\mathrm{C}$ & $-50 \mathrm{~mm}, \mathrm{pu}$ & 3 & 2 & 0 & 36 & 42 & 20 & 0 & 0 & 0 & 0 & 100 & 0 & 0 & 0 & 3 & 54 & 37 & 0 & 6 \\
\hline Sd153(L) & A & goma, v.c.sd.-g.g., $-10 \mathrm{~mm}, \mathrm{pu}$ & 21 & 30 & 0 & 39 & 11 & 21 . & 0 & 0 & 0 & 0 & 98 & 2 & 0 & 0 & 0 & 59 & 31 & 0 & 10 \\
\hline Sd153(M) & C & goma, p.g.,c.b.g., $-20 \mathrm{~mm}, \mathrm{pu}$ & 6 & & & & & & & & & & & & & & & & & & \\
\hline Sd153(U) & $\mathrm{C}$ & $-20 \mathrm{~mm}, \mathrm{pu}$, R.F. & 4 & & & & & & & & & & & & & & & & & & \\
\hline Sd154 & $\mathrm{C}$ & $-50 \mathrm{~mm}, \mathrm{pu}$ & 3 & 17 & 0 & 33 & 29 & 21 & 0 & 0 & 0 & 0 & 92 & 8 & 0 & 0 & 0 & 55 & 30 & 0 & 15 \\
\hline $\mathrm{Sd} 155$ & B & goma, v.c.sd.,c.b.g.,pu & 4 & 0 & 0 & 45 & 15 & 40 & 0 & 0 & 0 & 0 & 0 & 0 & 0 & 0 & 0 & 51 & 32 & 0 & 18 \\
\hline Sd156 & A & goma, g.g.,pu, $(-10 \mathrm{~mm}$, R.F. $)$ & 10 & * & 0 & 45 & 2 & 53 & 0 & 0 & 0 & 0 & 100 & 0 & 0 & 0 & 0 & 54 & 27 & 0 & 19 \\
\hline Sd 157 & A & whi, g.g., $-10 \mathrm{~mm}, \mathrm{pu}$ & 4 & 1 & 0 & 50 & 5 & 44 & 0 & 0 & 0 & 0 & 100 & 0 & 0 & 0 & 0 & 52 & 38 & 0 & 10 \\
\hline Sd158 & B & g.g.,c.b.g., $-5 \mathrm{~mm}, \mathrm{pu}$ & & 9 & 0 & 49 & 15 & 27 & 0 & 0 & 0 & 0 & 100 & 0 & 0 & 0 & 0 & 53 & 23 & 0 & 25 \\
\hline Sd159 & A & goma, co.sd.,c.b.g.,pu & 2 & 1 & 0 & 41 & 1 & 57 & 0 & 0 & 0 & 0 & 100 & 0 & 0 & 0 & 0 & 42 & 28 & 0 & 30 \\
\hline Sd160 & A & goma, g.g., $-5 \mathrm{~mm}, \mathrm{pu}$ & 5 & * & 0 & 49 & 4 & 47 & 0 & 0 & 0 & 0 & 100 & 0 & 0 & 0 & 0 & 51 & 36 & 0 & 13 \\
\hline Sd 161 & A & whi, p.g.,c.b.g., $-30 \mathrm{~mm}$,pu & 12 & 0 & 0 & 48 & 4 & 48 & 0 & 0 & 0 & 0 & 0 & 0 & 0 & 0 & 0 & 43 & 15 & 0 & 42 \\
\hline Sd162 & A & whi, p.g., $-20 \mathrm{~mm}$, pu & 3 & 3 & 0 & 42 & 12 & 43 & 0 & 0 & 0 & 0 & 100 & 0 & 0 & 0 & 0 & 37 & 24 & 0 & 40 \\
\hline Sd163 & A & goma, p.g.,c.b.g., $-10 \mathrm{~mm}$,pu & 3 & 3 & 0 & 41 & 8 & 49 & 0 & 0 & 0 & 0 & 100 & 0 & 0 & 0 & 0 & 50 & 29 & 0 & 21 \\
\hline Sd164 & A & goma, v.c.sd. & 2 & 0 & 0 & 43 & 5 & 53 & 0 & 0 & 0 & 0 & 0 & 0 & 0 & 0 & 0 & 49 & 28 & 0 & 23 \\
\hline Sd165 & $\mathrm{C}$ & p.g.,c.b.g., $,-10 \mathrm{~mm}, \mathrm{pu}$ & 8 & 15 & 0 & 43 & 27 & 15 & 0 & 0 & 1 & 3 & 96 & 0 & 0 & 2 & 0 & 36 & 21 & 0 & 41 \\
\hline Sd166 & $\mathrm{C}$ & p.g., $-10 \mathrm{~mm}, \mathrm{pu}$, R.F. & 17 & 4 & 0 & 43 & 31 & 22 & 0 & 0 & 0 & 0 & 100 & 0 & 0 & 0 & 0 & 50 & 18 & 0 & 32 \\
\hline Sd167 & $\mathrm{C}$ & p.g.,c.b.g., $-10 \mathrm{~mm}$,pu,R.F. & 3 & 4 & 0 & 49 & 33 & 13 & 0 & 0 & 0 & 0 & 90 & 0 & 10 & 0 & 0 & 39 & 23 & 0 & 39 \\
\hline Sd168 & B & p.g.,pu & & 0 & 0 & 43 & 23 & 35 & 0 & 0 & 0 & 0 & 0 & 0 & 0 & 0 & 2 & 47 & 26 & 0 & 25 \\
\hline Sd169 & $\mathrm{C}$ & p.g., $-10 \mathrm{~mm}, \mathrm{pu}$ & 3 & 4 & 0 & 48 & 28 & 20 & 0 & 0 & 0 & 0 & 100 & 0 & 0 & 0 & 0 & 60 & 23 & 0 & 18 \\
\hline Sd170 & A & goma, g.g.,pu,R.F. & 4 & 1 & 0 & 45 & 10 & 44 & 0 & 0 & 0 & 0 & 100 & 0 & 0 & 0 & 0 & 53 & 31 & 0 & 16 \\
\hline Sd171 & $\mathrm{C}$ & gra, p.g.,c.b.g., $-30 \mathrm{~mm}$,pu,R.F. & 4 & 3 & 0 & 44 & 19 & 34 & 0 & 0 & 0 & 0 & 100 & 0 & 0 & 0 & 0 & 50 & 24 & 0 & 26 \\
\hline Sd172 & $\mathrm{B}$ & p.g.,pu & & & & & & & & & & & & & & & & & & & \\
\hline Sd173 & $\mathrm{C}$ & g.g.,c.b.g., $-5 \mathrm{~mm}, \mathrm{pu}$, R.F. & 3 & 8 & 0 & 37 & 26 & 29 & 0 & 0 & 21 & 7 & 71 & 0 & 0 & 0 & 2 & 44 & 31 & 0 & 23 \\
\hline Sd174 & A & gra, v.c.sd.,pu & 3 & 1 & 0 & 34 & 9 & 56 & 0 & 0 & 0 & 0 & 100 & 0 & 0 & 0 & 0 & 53 & 24 & 0 & 23 \\
\hline Sd175 & A & gra, v.c.sd,pu & 6 & 20 & 0 & 45 & 10 & 25 & 0 & 0 & 0 & 0 & 100 & 0 & 0 & 0 & 6 & 44 & 35 & 0 & 15 \\
\hline Sd176 & A & gra, g.g., $-20 \mathrm{~mm}$,pu & 6 & 0 & 0 & 21 & 22 & 57 & 0 & 0 & 0 & 0 & 0 & 0 & 0 & 0 & 8 & 39 & 27 & 0 & 27 \\
\hline Sd177 & A & ora, p.g., $-10 \mathrm{~mm}, \mathrm{pu}$ & 6 & 2 & 0 & 53 & 22 & 23 & 0 & 0 & 0 & 0 & 100 & 0 & 0 & 0 & 18 & 41 & 8 & 0 & 33 \\
\hline Sd178 & A & bei, v.c.sd., $-5 \mathrm{~mm}, \mathrm{pu}$ & 7 & 0 & 0 & 43 & 7 & 50 & 0 & 0 & 0 & 0 & 0 & 0 & 0 & 0 & 0 & 60 & 17 & 0 & 23 \\
\hline Sd179 & B & v.c.sd. & 3 & 0 & 0 & 58 & 3 & 40 & 0 & 0 & 0 & 0 & 0 & 0 & 0 & 0 & 5 & 57 & 7 & 0 & 30 \\
\hline Sd180 & B & gra, c.sd. & 3 & 8 & 0 & 59 & 3 & 31 & 0 & 0 & 0 & 0 & 97 & 3 & 0 & 0 & 2 & 39 & 23 & 0 & 36 \\
\hline Sd181 & A & yel, g.g.,pu,R.F. & 6 & 4 & 0 & 35 & 38 & 24 & 0 & 0 & 0 & 0 & 100 & 0 & 0 & 0 & 48 & 41 & 0 & 0 & 11 \\
\hline Sd182 & $\mathrm{C}$ & p.g., $-30 \mathrm{~mm}, \mathrm{pu}$ & 2 & 0 & 0 & 42 & 48 & 9 & 0 & 0 & 0 & 0 & 0 & 0 & 0 & 0 & 82 & 13 & 3 & 0 & 2 \\
\hline Sd183 & A & yel, p.g.,c.b.g., $-20 \mathrm{~mm}$, pu,R.F. & 5 & 0 & 0 & 45 & 20 & 35 & 0 & 0 & 0 & 0 & 0 & 0 & 0 & 0 & 41 & 38 & 7 & 0 & 14 \\
\hline Sd184 & $\mathrm{C}$ & $-30 \mathrm{~mm}, \mathrm{pu}$ & 25 & 11 & 0 & 47 & 29 & 12 & 0 & 0 & 2 & 0 & 63 & 36 & 0 & 1 & 29 & 31 & 13 & 0 & 26 \\
\hline Sd185 & A & yel, p.g., $-10 \mathrm{~mm}, \mathrm{pu}$, R.F. & 24 & 1 & 0 & 51 & 24 & 23 & 0 & 0 & 0 & 0 & 100 & 0 & 0 & 0 & 2 & 50 & 27 & 0 & 21 \\
\hline Sd186 & C & yel, g.g., $-5 \mathrm{~mm}, \mathrm{pu}$, R.F. & 12 & 9 & 0 & 56 & 23 & 11 & 0 & 0 & 0 & 0 & 96 & 4 & 0 & 0 & 1 & 50 & 17 & 0 & 32 \\
\hline Sd187 & B & yel, p.g.,c.b.g., $-10 \mathrm{~mm}$, pu & & 0 & 0 & 53 & 14 & 33 & 0 & 0 & 0 & 0 & 0 & 0 & 0 & 0 & 0 & 43 & 24 & 0 & 33 \\
\hline Sd188 & $\mathrm{C}$ & yel, p.g., $-20 \mathrm{~mm}, \mathrm{pu}$ & 7 & 1 & 0 & 48 & 41 & 11 & 0 & 0 & 50 & 0 & 50 & 0 & 0 & 0 & 0 & 40 & 34 & 0 & 26 \\
\hline Sd189 & $\mathrm{C}$ & $-10 \mathrm{~mm}, \mathrm{pu}$ & 3 & 1 & 1 & 47 & 31 & 20 & 0 & 0 & 25 & 0 & 25 & 50 & 0 & 0 & 1 & 51 & 24 & 0 & 24 \\
\hline Sd190 & $\mathrm{A}$ & whi, g.g.,pu & 4 & 0 & 0 & 72 & 3 & 25 & 0 & 0 & 0 & 0 & 0 & 0 & 0 & 0 & 24 & 48 & 1 & 0 & 27 \\
\hline
\end{tabular}

空欄のところは，風化が激しく鉱物の同定が不可能であったすの. Tephra facies の空白になっているところは，いろ いろな色の火砕物または外来の岩片が交じり合うなど，単一の色で示すことが困難なむの. 